OPEN ACCESS

Approved by:

Psychology Editorial Office, Frontiers Media SA, Switzerland

${ }^{*}$ Correspondence:

Frontiers Production Office production.office@frontiersin.org

Specialty section: This article was submitted to Cognition, a section of the journal Frontiers in Psychology

Received: 01 June 2018 Accepted: 04 June 2018

Published: 21 June 2018

Citation:

Frontiers Production Office (2018) Erratum: Effects of social gaze on visual-spatial imagination.

Front. Psychol. 9:1053. doi: 10.3389/fpsyg.2018.01053

\section{Erratum: Effects of social gaze on visual-spatial imagination}

\author{
Frontiers Production Office* \\ Frontiers Production Office, Frontiers Media SA, Lausanne, Switzerland
}

Keywords: visual-spatial imagery, eye-closure, gaze aversion, social interaction

\section{An erratum on}

\section{Effects of social gaze on visual-spatial imagination}

by Buchanan, H., Markson, L., Bertrand, E., Greaves, S., Parmar, R., and Paterson, K. B. (2014). Front. Psychol. 5:671. doi: 10.3389/fpsyg.2014.00671

An error in the editor name was introduced during typesetting. The correct editor name is Timothy John Hollins.

The publisher apologizes for this error and the original article has been corrected. This error does not change the scientific conclusions of the article in any way.

The original article has been updated.

Copyright ( 2018 Frontiers Production Office. This is an open-access article distributed under the terms of the Creative Commons Attribution License (CC BY). The use, distribution or reproduction in other forums is permitted, provided the original author(s) and the copyright owner are credited and that the original publication in this journal is cited, in accordance with accepted academic practice. No use, distribution or reproduction is permitted which does not comply with these terms. 